\title{
Solar hydrogen energy: the European/Maghreb connection a new way of excellence for a sustainable energy development
}

\author{
A. Cherigui ${ }^{1 *}$, B. Mahmah ${ }^{2}$, M. Belhamel $^{2}$, \\ S. Chader ${ }^{2}$, A. M'Raoui ${ }^{2}$, F. Harouadi ${ }^{2}$ and C. Etievant ${ }^{3}$ \\ 1 \\ Sciences \& Technologies, Université Joseph Fourier, Grenoble 1, \\ B.P. 87 , Saint-Martin d'Hères, 38400, France \\ Centre de Développement des Energies Renouvelables, \\ B.P. 62, Route de l'Observatoire, Bouzaréah, Alger, France \\ 3 Compagnie Européenne des Technologies de l'Hydrogène \\ CETH Innov’Valley Entreprises, 91460 Marcoussis, France \\ (reçu le 10 Mars 2007 - accepté le 25 Décembre 2007)
}

\begin{abstract}
The global sustainability is a key word of the future energy system for human beings. It should be friendly to our earth. Hydrogen energy is a critical resource to sustainable energy development. Over the coming decades, rapid economic growth will necessitate expanded and diversified energy supplies. This study is proposed to illustrate the attention to the opportunities and possibilities of connecting the energy consumer in North Mediterranean countries, to the reservoir of the Great Sahara of North Africa using hydrogen as a solar energy carrier. It also discusses cooperation between North Africa and north sides of the Mediterranean that has been going on for a long time, in oil and natural gas industry, and why can not be done in solar hydrogen energy industry, which will reduce pollution and will last for ever. Clearly, North Africa is major bilateral partner with the Europe and the people of the two shares of the Mediterranean will be work together and to built strategic relationships for many decades. In the future, North Africa countries are wellpositioned to play a greater role in the Europe clean energy equation. Demographically, interregional migration due to economic concerns will decline. Now, there are good chances to start such cooperation for the benefits of all partners.

Résumé - La durabilité mondiale est un mot clé du futur système d'énergie pour les êtres humains. Il doit être respectueux de notre terre. L'hydrogène énergie est une ressource essentielle pour un développement énergétique durable. Dans les prochaines décennies, une croissance économique rapide est attendue nécessitant un élargissement et une diversification dans l'approvisionnement en énergie. Cette étude se propose d'illustrer l'attention sur les opportunités et les possibilités de connexion pour l'approvisionnement énergétique dans les pays de la Méditerranée du Nord à partir $d u$ réservoir $d u$ Grand Sahara de l'Afrique du Nord en utilisant l'hydrogène comme vecteur énergétique renouvelable. Cette étude examine également la coopération entre les pays de l'Afrique du Nord et ceux du Nord de la Méditerranée, qui date depuis longtemps, dans l'industrie pétrolière et gazière, et pourquoi pas qu'elle ne se fasse pas dans l'industrie solaire, avec l'hydrogène, afin de permettre la réduction de la pollution. Manifestement, les pays de l'Afrique du Nord sont les principaux partenaires bilatéraux avec l'Europe et les peuples des deux parties de la Méditerranée seraient de travailler ensemble et de construire des relations stratégiques pour les prochaines décennies. Dans l'avenir, les pays d'Afrique du Nord sont bien placés pour jouer un grand rôle en Europe dans les énergies propres. Démographiquement, les migrations interrégionales en raison de préoccupations économiques vont diminuer. Maintenant, il existe de bonnes chances pour entamer une telle coopération avantageuse pour l'ensemble des partenaires.
\end{abstract}

Keywords: Solar hydrogen energy - Maghreb - Europe - Connection - Security supply.

\section{INTRODUCTION}

North African countries have an optimum solar resource, being essentially arid or semi arid, other than petroleum and natural gas whose reserves are limited and they have been declining.

* To whom correspondence should be addressed: Abdel-Nasser Cherigui, Université Grenoble 1; BP 87 Saint-Martin-D’Hères 38400 France; E-mail: acherigui fuelcell2050@yahoo.com 
North African countries could face an energy deficit within the next decades [1]. Solar energy appears to be the only logical option. On the other side, the European Union, EU, for instance, is requiring its members to boost electricity from renewable to $22 \%$ of production by 2010 [2]. The first demonstration plants of solar hydrogen energy could be built and operated in cooperation between countries with clean energy shortages and with increasing pollution, but having advanced technology and Know How Exchange, EU, and countries with abundant clean solar energy, but in shortages of advanced technology.

North Africa countries have the largest Sahara of Africa; it extends between the Western Sahara in the West and Libya in the East. It is also bordered by the Atlas Mountains and the Mediterranean Sea in the North, with about $2600 \mathrm{kWh} / \mathrm{m}^{2}$ annual solar irradiance and 3500 hours of sunshine [3]. It represents a huge reservoir of clean energy that could supply Europe with its energy needs for centuries without fear of depletion (Fig. 1). This reservoir of solar energy is located just the south of Europe, where the infrastructure for energy transportation to Europe, undersea pipe lines and tankers, is available. The main goal of this paper is to draw the attention of the governments and businesses in Maghreb and in the EU to the opportunities and possibilities available now to start cooperation in exploiting this clean energy, in the same way done between the two sides in exploiting oil and natural gas. Some oil companies (Total, Shell, BP, ...) are now investing in solar and hydrogen energy around the world.

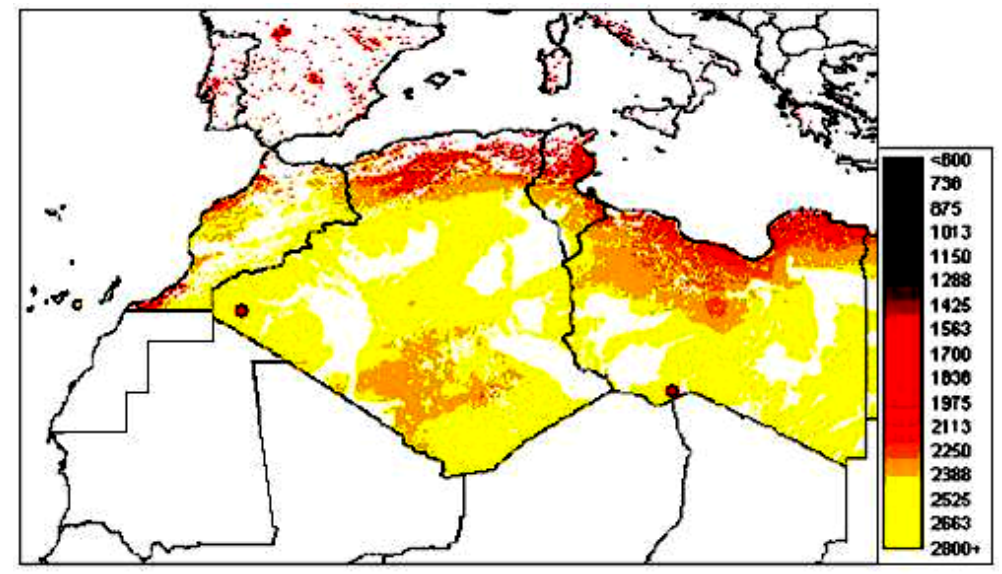

Fig. 1: Annual direct normal irradiance in $\mathrm{kWh} / \mathrm{m}^{2} / \mathrm{y}$. MED-CSP 2005 [3]

If the oil and gas companies working in NA countries install small demonstration plants near their oil fields, that can be included in the original contracting, as joint venture, between the two sides, then few demonstration plants will be operating in few years, and the available technologies can be tested and evaluated in a real live conditions, and many experimental and field work can be executed that could lead to more development of applied technology. This is an invitation to EuroSolar, 5+5, Oil Companies and others concerned with $\mathrm{CO}_{2}$ emissions and sustainable development of the world, to do something together.

\section{SALIENT FACTORS FOR THE RELATIONS BETWEEN EU-MAGHREB REGIONS}

The region of EU-MAGHREB is coined by tremendous differences between its parts. There are significant differences such as:

1. level of literacy and vocational education

2. income per capita

3 . religion 
4. participation of population in public/societal matters

5. industrialization

6. significance of science and technology

7. gender equality

8. climate living conditions.

It is not exaggerating to say that the regions Europe on one side and Maghreb on the other are separated by a large cultural and infrastructural gap. But by the history and by geography they are neighbours, and they have significant commons. The most important and challenging common however is their future. The process of globalization leaves no perspective for continued separation. Modern means of communication and transport irreversibly put an end to sealed societies. Problems, unrest and wars cannot be concealed. Globalization is a challenge to the Mediterranean riparian countries to pay careful attention to how the shape their common future. Are we doomed to a clash of civilizations or can we use differences as complementing capacities for synergies, in support of achieving common goals? In fact, there are goals that either side would consider as an advantage:

a. peace within and between these regions

b. energy security

c. water security

d. environmental stability

e. sustainable and fair prosperity.

The study demonstrates how cooperation for hydrogen energy could generate win-win configurations and bring all these goals into reach. Some remaining questions are:

1. could the common goals overcome frictions and suspicions based on cultural differences?

2. can these regions co-operate without endangering their cultural identities?

3. can all countries become winners of a co-operation?

A positive answer to question 1 is the big hope fort he common future of theses regions. In fact, co-operation for the use of Hydrogen energy bears the promise of enclosing or even of eliminating the frictions due to the present struggles for access to the limited fossil energy resources in North African countries. The answer to question 2 depends on the intention behind the co-operation. If the intention of one side is to impose its cultural values onto the others, then co-operation will no longer be embraced by the others. The drive for any cultural or societal development must be coming from inside the respective society. The frameset for co-operation on renewable energies must exclude its abuse for cultural, economic or political hegemony. Question 3 can be answered with a clear yes if proper political and economic general conditions were in place. In summary, a proper political framework for hydrogen energy partnership must

1- Enable feasibility and enhance productivity of the co-operation

2- Ensure advantages for all sides

3- Support stability of the interregional relations

4- Bar the abuse for hegemony and cultural domination.

\section{SCENARIO FOR SOLAR HYDROGEN ENERGY VIA SUSTAINABLE ELECTRICITY - S2HE}

The S2HE demonstrates the capability of a well balanced mix of renewable and fossil energy sources to provide secure, inexpensive and sustainable electricity for the supply of each of the European countries. Renewable energy can provide the necessary amount of clean energy to achieve the targets for climate stabilization and reduce the consumption of fossil fuels to the rare times when renewable energy supply and electricity demand do not coincide. The strategy of reducing fossil energy use to peaking power allows for firm capacity on demand and at the same time reduces the reduces the consumption of fossil fuels that are a very valuable, ideally stored 
form of energy that should be exclusively used for that purpose. Europe has plenty renewable energy sources for power generation (Table 1).

Table 1: Renewable energy resources maps for the European regions and Algeria

All demand sum up to $5160 \mathrm{TWh} /$ Year. The total future electricity demand of the analyzed countries amounts to about $4000 \mathrm{TWh}$ per year.

\begin{tabular}{lc}
\hline Resources maps & Energy demand (TWh/year) \\
\hline Biomass & 620 \\
Geothermal & 380 \\
Wind energy & 1520 \\
Hydropower & 910 \\
Solar energy & 1730 \\
Solar Energy (Algeria) & $\mathbf{1 6 9 4 4 0}$ \\
\hline
\end{tabular}

Their total economic potential amounts to about $145 \%$ of the expected future electricity demand. This suggests that the coverage of the demand by $100 \%$ should be achievable within a time span 50 years. However, $60 \%$ of this potential comes from wind and solar energy, both fluctuating resources that can provide electricity, but almost no firm power capacity on demand (Table 2). Moreover, the potentials are not distributed uniformly, but are concentrated in typical regions, e.g., hydropower in Scandinavia and the south central mountains, solar energy in the south, wind energy at the northern coasts and geothermal energy in south and Eastern Europe. Therefore, only $80 \%$ of the power mix of the year 2050 will be derived from renewable energies.

Table 2: Some characteristics of contemporary power technologies

\begin{tabular}{|c|c|c|c|c|c|}
\hline & $\begin{array}{c}\text { Unit } \\
\text { Capacity }\end{array}$ & $\begin{array}{l}\text { Capacity } \\
\text { credit * }\end{array}$ & $\begin{array}{l}\text { Capacity } \\
\text { factor } * *\end{array}$ & Resource & Application \\
\hline Wind Power & $1 \mathrm{~kW}-5 \mathrm{MW}$ & $0-30 \%$ & $15-50 \%$ & $\begin{array}{c}\text { Kinetic energy of } \\
\text { the wind }\end{array}$ & Electricity \\
\hline Photovoltaic & $1 \mathrm{~W}-5 \mathrm{MW}$ & $0 \%$ & $5-25 \%$ & $\begin{array}{l}\text { Direct and diffuse } \\
\text { irradiation on a } \\
\text { tilted surface }\end{array}$ & Electricity \\
\hline Biomass & $1 \mathrm{~kW}-25 \mathrm{MW}$ & $50-90 \%$ & $40-60 \%$ & $\begin{array}{c}\text { Biogas from the } \\
\text { decomposition of } \\
\text { organic residues, } \\
\text { solid residues and } \\
\text { wood }\end{array}$ & $\begin{array}{c}\text { Electricity and } \\
\text { Heat }\end{array}$ \\
\hline $\begin{array}{l}\text { Geothermal } \\
\text { (Hot Dry } \\
\text { Rock) } \\
\end{array}$ & $25-50 \mathrm{MW}$ & $90 \%$ & $40-90 \%$ & $\begin{array}{c}\text { Heat of hot dry } \\
\text { rocks several } \\
1000 \mathrm{~m} \text { depth } \\
\end{array}$ & $\begin{array}{c}\text { Electricity and } \\
\text { Heat }\end{array}$ \\
\hline Hydropower & $\begin{array}{c}1 \mathrm{~kW}-1000 \\
\mathrm{MW}\end{array}$ & $50-90 \%$ & $10-80 \%$ & $\begin{array}{c}\text { Kinetic energy } \\
\text { and pression of } \\
\text { water stream }\end{array}$ & Electricity \\
\hline Solar Updraft & $100-200 \mathrm{MW}$ & $\begin{array}{c}10 \text { to } 70 \% \\
\text { depending on } \\
\text { storage }\end{array}$ & 20 to $90 \%$ & $\begin{array}{l}\text { Direct and diffuse } \\
\text { irradiation on a } \\
\text { horizontal surface }\end{array}$ & Electricity \\
\hline $\begin{array}{l}\text { Concentrating } \\
\text { Solar Thermal } \\
\text { Power }\end{array}$ & $\begin{array}{l}10 \mathrm{~kW}- \\
200 \mathrm{MW}\end{array}$ & $\begin{array}{c}0 \text { to } 90 \% \\
\text { depending on } \\
\text { storage and } \\
\text { hybridization }\end{array}$ & 20 to $90 \%$ & $\begin{array}{l}\text { Direct irradiance } \\
\text { on a surface } \\
\text { tracking the sun }\end{array}$ & $\begin{array}{c}\text { Electricity and } \\
\text { Heat }\end{array}$ \\
\hline Gas Turbine & $0.5-100 \mathrm{MW}$ & $90 \%$ & $10-90 \%$ & $\begin{array}{l}\text { Natural gas, } \\
\text { fuel oil }\end{array}$ & $\begin{array}{c}\text { Electricity and } \\
\text { Heat }\end{array}$ \\
\hline Steam Cycle & $5-500 \mathrm{MW}$ & $90 \%$ & $40-90 \%$ & $\begin{array}{l}\text { Coal, lignite, fuel } \\
\text { oil, natural gas }\end{array}$ & $\begin{array}{c}\text { Electricity and } \\
\text { Heat }\end{array}$ \\
\hline Nuclear & $>500 \mathrm{MW}$ & $90 \%$ & $90 \%$ & Uranium & $\begin{array}{c}\text { Electricity and } \\
\text { Heat }\end{array}$ \\
\hline
\end{tabular}




\section{GLOBAL CONTEXT: ENVIRONMENTAL STATE}

The development of renewable energy sources and rationale use of energy was a central aim of the world energy policy in last decade. The limitations in the exploitation of conventional energy resources and the necessity of the reform energy policies have given new impulse in development of these environmental friendly energy technologies. In this context, NA countries signed and ratified into the United Nations Framework Convention on Climate Change (UNFCCC). In addition, Algeria has recently accessed the Tokyo Protocol. However, since 1994, $\mathrm{CO}_{2}$ emissions have increased and the contribution of renewable energy sources in Maghreb is strongly low.

Maghreb is able to take a more active part in the development of new technologies for exploiting and utilizing renewable energy. Maghreb has significant potential for exploiting renewable energy, and has an area where many remote villages can benefit from renewable energy sources applications. Application of solar energy has already been developed and can be assured as matured. The best of our knowledge, renewable energy sources and rationale use of energy available information in Maghreb is still rare in the international literature.

\section{NORTH AFRICAN'S ENERGY RESERVES EXAMPLE OF ALGERIA}

The first oil discovery in Algeria was made in 1948 at Oued-Gueterini near Sidi-Moussa. Algeria reserves of oil are about $11.810^{9}$ barrels [4]. Algeria consumed 246,000 barrels per day in 2004 , some $13 \%$ of its production ( $0.3 \%$ of world total energy consumption). Algeria ranks the $3^{\text {rd }}$ among the oil producing countries of Africa and the $12^{\text {th }}$ in the world. Algeria's Sahara blend oil $45^{\circ} \mathrm{API}$ with negligible $(0.05 \%)$ sulphur content is among the highest quality the world. World reserves of oil are about $1.010^{12}$ barrels [4] and world consumption is about $75.010^{6}$ barrels $\left(8.610^{6} \mathrm{t}\right)$ a day. World reserves of natural gas are about $1.410^{14} \mathrm{~m}^{3}$, gross production of gas is about $2.410^{12} \mathrm{~m}^{3}$ per day [5]. An Algerian reserve of natural gas is about $4.610^{12} \mathrm{~m}^{3}$, the seventh-largest in the world and is the second-largest gas exporter. Only $15 \%$ of the total has actually been produced.

In 2004, Algeria consumed $29 \%$ of its production. The Algerian government has encouraged the domestic use of natural gas which now represented over $63 \%$ of the country's total energy consumption in 2004. World coal reserves are about $9.110^{11}$ tons. Annual consumption is about $4.510^{9}$ tons per year. Algerian coal reserves are 44 millions tons. Algeria generated $25.810^{9} \mathrm{kWh}$ of electricity in 2002 [5].

Conventional thermal sources of which natural gas accounted for $97 \%$, contributed almost all of Algeria's electricity supply, supplemented by a small amount of hydroelectricity. As of 2002, Algeria had $5.93 \mathrm{GW}$ of installed generating capacity. Algeria's electricity demand is growing at a rapid rate and the country will require significant capacity incoming years.

\section{THE GREAT SAHARA OF NORTH AFRICA}

The great Sahara covers $86 \%$ of the entire countries, and it represents the largest Sahara in the world. With its high solar insolation, long hours of sunshine and about $82 \%$ unused land, it can be considered as limitless source of clean energy that can supply Europe with more than of its energy requirements for long centuries.

The North Africa countries with high population growth rate, $2 \%$, and willingness to better their lives, are demanding more energy to meet the new population needs and to improve the quality of life of the existing people. This means connecting electricity to every home in villages 
scattered in or around the desert which is impossible to do with the existing energy centralized systems. Few of these regions possess limited electricity and water resources.

\section{EUROPE AND CLEAN ENERGY REQUIREMENTS}

Global energy demand is expected to triple by mid-century and Europe will have a huge piece of this amount of energy 73 million TJ, for 2000 and 300 million TJ, for 2050 [6] required to move the world. If it is supplied by burning fossil fuels, it would produce shout 3 billion metric tons of $\mathrm{CO}_{2}$ alone. Investing in solar energy of North Africa will help the people living in the Sahara or on its borders develop their life due to receiving electricity and other forms of clean energy, that could result in stabilizing the region, by creating jobs and prosperity. Also, some people would stop cutting trees and others reduce burning of fossil fuels, thus reducing their share of $\mathrm{CO}_{2}$ emissions.

\section{MAGHREB, EUROPE AND ENERGY RELATIONSHIP}

Maghreb is one of EU's strategic partners. Maghreb and Europe, looking at each other-face to face- through the Mediterranean Sea, have established a vital energy relationship for a long time, and it appears that there is no alternative for its continuation through the next decades. In the past, some of Maghreb countries imported coal from Europe to generate some of their electric power required to start modernization of their countries. Later on, the trend is reversed, where European companies have invested, a lot of money exploring for oil, and then natural gas, in the region, which also included production, transportation, refining and consumption.

There are now undersea pipe lines transporting natural gas from Algeria to Italy and Spain, and from Libya to Italy, where it can be distributed to whole continent (Fig. 2) and is expected to continue with fossil fuels, but what this paper is calling for is to widen this energy relationship to include solar and solar hydrogen energy, in order for these energy and other relationships to be sustainable development for many decades to come. Now, both sides of the Mediterranean are, and will be, facing some problems that can affect both of them in the future.

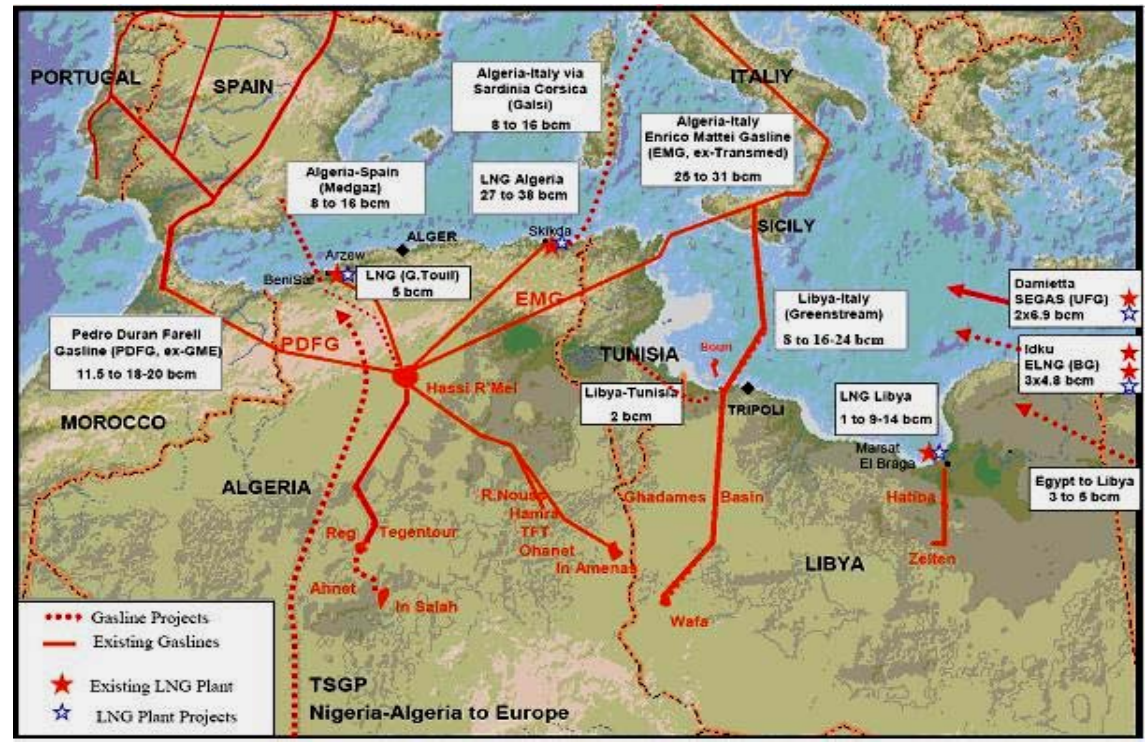

Fig. 2: Undersea Pipe lines from Algeria \& Libya to Spain \& Italy [7, 8] 
Increasing energy demand, on both sides, complication of the pollution problems, on northern side, unemployment, on both sides, diminishing traditional energy resources that will affect both sides. Taking the above problems seriously, thinking in the next generation, thinking the relations between oil companies and local governments as an example, there is no doubt that some small projects, at least, can be started to exploit solar that can be tram ported to Europe in the Form of gaseous hydrogen through undersea pipe lines.

For practical example: Oil Companies working in the region, in agreement with local governments, can include small solar hydrogen projects and construct them around their oil fields, that can be operated with cooperation between solar energy institutions in both sides.

\section{HASSI R'MEL SOLAR VALLEY PROJECT IN ALGERIA}

In 2002, Sonatrach and Sonelgaz formed a new, renewable energy joint venture company, called New Energy Algeria or NEAL, have invited expressions of interest in a hybrid solar-gas project that will be set up at Hassi R'mel.

The complex will comprise a 130 MW combined cycle, with a gas turbine power of the order of $80 \mathrm{MW}$ and a $75 \mathrm{MW}$ steam turbine. A $25 \mathrm{MW}$ solar field, requiring a surface of around $180.000 \mathrm{~m}^{2}$ of parabolic mirrors, will be the source of non-fossil energy.

Successful management of this technology will enable costs to be reduced and solar energy to become a supplementary source to hydrocarbons for future generations as well as for exporting electricity to Europe. Investments of nearly 140 million US \$ will be contributed by the German Investment Bank KFW and the European Investment Bank.

\section{CONCLUSION}

There is a real need to develop solar hydrogen projects in Maghreb to harness the energy reservoir for the benefits of both sides of the Mediterranean, and for the planet earth. We are confident this Forum will further advance our understanding of the mutual benefits to be derived from enhancing our relationship and from overcoming obstacles in increased bilateral trade.

\section{ACKNOWLEDGMENTS}

We acknowledge fruitful discussions with many colleagues; N. Veziroglu, T. Alleau, J.W. Sheffield, in particular have offered valuable suggestions. This work brings in within the framework of the Maghreb-Europe Project (Hydrogen Production by Solar way). The content of this paper is the sole responsibility of its authors.

\section{REFERENCES}

[1] Central Intelligence Agency - Factbook 2005, Maghreb.

[2] European Commission, Directorate-General for Energy and Transport, European Energy and Transport Trends to 2030, 2002.

[3] MED-CSP 2005/ MED-CSP Study Team, 'Concentrating Solar Power for the Mediterranean Region', Study commissioned by the German Federal Ministry for the Environment, Nature conservation and Nuclear Safety, Stuttgart 2005, www.dlr.de/tt/med-csp

[4] US Energy Information Administration, (EIA), Algeria Country Analysis Brief, March 2005.

[5] The World Bank Group Data for Algeria 2005.

[6] The World Bank Group Data for the World, 2004, 2005.

[7] Mark Hayes, 'Algerian Gas to Europe: the Transmed Pipeline and Early Spanish Gas Import Projects', Geopolitics of Natural Gas Study, Project of the Program on Energy and Sustainable Development, Stanford University, May 2004. 
[8] M. Hafner, 'Approvisionnement à Long Terme de Gaz Naturel pour l'Europe: Potentiel d'Importation et Besoin d'Infrastructures', Observatoire Méditerranéen de l'Energie, VI Forum: 'Energie et Géopolitique', Club de Nice, 30 Novembre 2007. 